\title{
CORRESPONDENCE
}

\section{CEPHALIC SEGMENTATION AND SUTURES IN TRILOBITES}

SIR,--While one agrees in principle with Dr. Stubblefield's caution (1950), several considerations exist to justify further investigation on the hypothesis that the pseudofrontal lobe of the glabella in trilobites may be trisegmental in origin (Lamont, 1949).

Most authors unquestioningly follow Bernard in saying the trilobite compound eye represents the first segment of the annelid ancestor, but sensory tubercles arranged along raised lines, or sutures, behind those of the compound eyes in Scotoharpes domina (Lamont) and Platyharpes flanaganni (Portlock) var. ?, indicate that several segments of the ancestor must have had eyes. Consideration of Dionide - and probably of Protolloydolithus (Williams, 1948)-points to the three transverse lines on each cheek as arising from the pseudo frontal lobe and indicating its trisegmental nature. Again, the compound basal glabellar lobes in Dionide are quite like those in Lioharpes. From homology between Dionide and Harpedidae, it is therefore easy to argue that the three transverse lines in Dionide added to the posterior pair that have recently been observed in Platyharpes, etc., provide evidence that the forerunner, at least of this group of trilobites, had five pairs of dorsal eyes on a pattern corresponding with that found in the modern leech (Hirudo medicinalis). Among other things this new theory allows Ruedemann's much criticized observations (1916, pl. 35, figs. 6 and 7) to be rationally interpreted. In his figures of Cryptolithus tesselatus Green, longitudinal sutures seem to pre-date lateral spreading of the glabella, and three pairs of transverse sutures, or eyelines, are present.

My observations of trisegmentation of the pseudofrontal lobe in adult males and females of Platycalymene duplicata (Murchison) have been queried by Dr. Stubblefield. The structures I photographed (1949, pl. xviii, figs. 3 and 4) still look like appendifers to me, and I don't see why they should have been preserved in a thin-shelled trilobite if they were not functional. In any case, there is apparent trisegmentation of a similar aspect in what may be taken as young adult males of Ogygiocaris buchii (Brongniart) (Salter, 1865 , pl. xiv, fig. 4) - cf. superior development of anterior appendages in males of crabs like Gonoplax angulatus (Cunningham, 1900, fig. 28). Lack of correspondence between number of appendages and number of dorsal segments in embryos of Limulus polyphemus (Woodward, 1866-1878, pl. xxxiii, figs. 2 and 4) may furnish a warning about reliance on the unsegmented or occasional bisegmental appearance of the pseudofrontal lobe in protaspid or meraspid trilobites.

The trisegmental "basal" glabellar lobes in Phillipsia colei McCoy, an Irish trilobite occurring late in the stratigraphical column but probably indicating the ancestral condition of many Proetidae and Otarionidae, have been clearly figured by Woodward (1883, pl. ii). In this form the middle part of the facial suture appears to homologize with the longitudinal suture in Harpedidae, lying close to the glabella and its "basal" lobes. While trisegmentation of "basal" lobes in Harpedidae is less clear, the raised lines running out from them on to the alae in primitive and less well calcified species, seems to point to a like interpretation. This may involve the idea that the compound eyes in Proetidae are not homologous with the anterior compound eyes in Harpedidae. Such a conclusion seems very likely if we consider Brachymetopus strzeleckii McCoy, in which, in addition to the posterior compound eyes, there are strong anterior tubercles in a position roughly corresponding with the anterior compound eyes of Harpedidae (Cowper Reed, 1903, p. 194, fig. 1).

In the Agnostidae, marked like the Illaenidae by reduction or suppression of maxillipedal and masticatory appendages, it is possible that the "basal " lobes may have been trisegmental. While the posterior part of the glabella is much reduced in length, it is interesting that the anterior often retains 
three transverse furrows. Muscle-scars in the agnostid Phalacroma glandiforme (Angelin) (Westergård, 1946, pl. 16, fig. 1) show fusion much like that in "Illaenus" proles var. shelvensis Whittard (Lamont, 1939, fig.), and adaptiveness makes it very difficult to trace ancestral segmentation in such families.

Most trilobites show reduction in the number either of the anterior three segments of the glabella or of the posterior three segments. This is the source of the view that there are five segments in the glabella, but the theory that there were originally six segments plus the occipital ring makes for much more intelligible homologies with Arachnida on the one hand and with Vermes on the other. A new interpretation of the trilobite hypostome in terms of prostomium and peristomium of certain worms may also be possible. On the hypostome of Dalmanites caudatus (Brunnich) (Salter, 1849, dec. ii, pl. $i$, fig. 3) and on that of a new late Caradoc species of Chasmops, not only are there the well known paired maculae, but near the posterior border occur three pits possibly for small appendages. The maculae may be thought of as comparable with the ciliated pits of the peristomium in Polygordius neapolitanus, while the other three pits may indicate the odd number of tentacles seen on the prostomium of marine worms. While naturally no one modern worm can be found to represent an ancestral form for all trilobites, the homologies of the trilobite cephalon now proposed may help to dispose of a theory like that by Ivanov concerning a polyphyletic origin for the trilobites.

\section{Grant INSTITUTE OF GEOLOGY,}

ArChie LAMONT.

$$
\begin{aligned}
& \text { WEST MAINS ROAD, } \\
& \text { EDINBURGH, } 9 .
\end{aligned}
$$

25tk May, 1950.

\section{REFERENCES}

Cunningham, J. T., 1900. Sexual Dimorphism in the Animal Kingdom. London.

Lamont, A., 1939. Cranidial Muscle-Scars in Illaenus proles var. shelvensis Whittard. Nature, cxliv, 206-7.

1948. Indications of Cephalic Sutures in Trinucleidae and Harpedidae. Ibid., clxii, 376-7.

1949. New Species of Calymenidae from Scotland and Ireland. Geol. Mag., Ixxxvi, 313-323.

ReED, F. R. C., 1903. Brachymetopus strzeleckii McCoy, 1847. Geol. Mag., $\mathrm{xl}, 193-6$.

Ruedemann, R., 1916. The Cephalic Suture Lines of Cryptolithus, N.Y. State Mus. Bull., No. 189.

Salter, J. W., 1849. British Organic Remains, decade ii. Mem. Geol. Surv. U.K.

1865. Monograph of British Trilobites. Palaeont. Soc.

Stubriefield, C. J., 1950. Remarks on Dr. Lamont's Interpretation of Features in the Trilobite Platycalymene, Geol. Mag., 1xxxvii, p. 67.

Westergård, A. H., 1946. Agnostidae of the Middle Cambrian of Sweden. Sier. Geol. Undersökn. Ser. C, No. 477.

Whitmington, H. B., 1950. Monograph of British Trilobites of the Family Harpidae. Palaeont. Soc.

Winliams, A., 1948. The Lower Ordovician Cryptolithids of the Llandeilo District. Geol. Mag., lxxxv, 65-88.

WOOdWARD, H., 1866-78. Monograph of British Fossil Merostomata. Palaeont. Soc.

1883. Monograph of British Carboniferous Trilobites, Ibid. 